\title{
Insertion/deletion of angiotensin-converting enzyme gene polymorphism as a marker of polycystic ovary syndrome (PCOS) development in South Indian cohort women
}

\author{
Nishu Sekar ${ }^{\mathrm{a}, \mathrm{b}}$, Abilash Valsala Gopalakrishnan ${ }^{\mathrm{a}}$ \\ aDepartment of Biomedical Sciences, School of BioSciences and Technology, VIT, Vellore, Tamil Nadu 632014, India \\ 'Sri Ramakrishna College of Arts and Science (Autonomous), Affiliated to Bharathiar University, Coimbatore, Tamil Nadu 641006, \\ India \\ Received 17th December 2017 / Accepted 11th April 2020
}

\begin{abstract}
Polycystic ovary syndrome (PCOS) is an endocrine/metabolic disease because of the elevated levels of androgen which could lead to anovulation. The angiotensin-converting-enzyme $(A C E)$ is a zinc metallopeptidase that converts angiotensin I to angiotensin II. $A C E$ is bound to the plasma membrane and expressed in many tissues such as ovarian tissues. The renin-angiotensin system (RAS help the production of angiotensin, angiotensinogen, and $A C E$. Angiotensin II plays a major role in ovulation, steroidogenesis, follicular atresia and hyperandrogenic syndromes such as PCOS. This study aimed to determine the association of $A C E$ polymorphism in PCOS to analyze the distribution allele frequency of insertion or deletion variation in PCOS patients of the South Indian cohort. A total of 430 women with PCOS confirmed based on the Rotterdam criteria and 300 age and sex-matched control samples were studied. PCR technique was used to determine the frequency of polymorphism in the ACE gene. The genotyping distribution of II, DD and ID in PCOS was 4.56\%, 30.23\%, and 65.11\%, respectively, whereas the control group showed 30\%, 20\%, and 50\% for II, DD and ID, respectively. The deletion (D) allele frequency was $62.79 \%$ and insertion (I) allele was $37.2 \%$ in PCOS patients, whereas in the control group, it was $45 \%$ and $55 \%$ for $\mathrm{D}$ and I alleles, respectively. This study concludes that the distribution of deletion (D) allele frequency of $A C E$ could be considered as a genetic marker for PCOS in the South Indian cohort.
\end{abstract}

Keywords: $A C E$ Gene, Cohort, PCOS, PCR

\section{INTRODUCTION}

Polycystic ovary syndrome (PCOS) is an endocrine/metabolic disease because of the elevated levels of androgen that could lead to anovulation in 5-10\% women of reproductive age (Brassard et al., 2008). Several genes involved in insulin secretion, energy metabolism, steroid biosynthesis, and gonadotropin action have shown altered expression in PCOS (Prapas et al., 2009). Although the role of genetic factors is strongly supported in the development of PCOS (Goodarzi et al., 2006), the genetic pathogenesis of
PCOS is not well established at the molecular level. Since there is no gold standard diagnosis for PCOS, three different assessment criteria have been used, i.e. the National Institutes of Health criteria (Zawadski and Dunaif, 1992), the Rotterdam criteria (Rotterdam, 2004) and the Androgen-Excess PCOS criteria (Azziz et al., 2009).

Ovarian renin-angiotensin system (RAS) has been reported to associate with PCOS and hyperandrogenism (Jaatinen et al., 1995; Palumbo

\footnotetext{
*Author for correspondence: Abilash Valsala Gopalakrishnan, Department of Biomedical Sciences, School of BioSciences and Technology, VIT, Vellore, Tamil Nadu 632014, India. Email - abilash.vg@vit.ac.in
} 
et al., 1993). The follicular fluid of ovary has 100fold of prorenin level compared with normal plasma levels (Glorioso et al., 1986). The increasing level of prorenin during ovulation is directly associated with a total number of mature oocyte follicles (Itskovitz, 1987). The angiotensinconverting-enzyme $(A C E)$ is a main effector molecule of the RAS, converting angiotensin I to angiotensin II. This enzyme is involved in the ovulation process, maturation of the oocyte, steroidogenesis, and development of corpus luteum (Yoshimura, 1997). The angiotensin Iconverting enzyme, encoded by the $A C E$ gene, was found in chromosome 17 and locus q23 and has 26 exons and 25 introns (Sayed-Tabatabaei et al., 2006). The concentration of the angiotensin Iconverting enzyme was determined by the insertion or deletion polymorphism of the $A C E$ gene (Elshamaa et al., 2011; Rigat et al., 1990) reported that individual variation in plasm concentration of angiotensin I-converting enzyme was dependent on the insertion (I)/deletion (D) polymorphism in $16^{\text {th }}$ intron of the $A C E$ gene. DD or DI genotypes were common in PCOS women (Ozegowska et al., 2016; Ozegowska et al., 2019). Homozygous deletion (D/D) has the highest level of angiotensin I-converting enzyme whereas homozygous insertion (I/I) gene type has the lowest level of the enzyme. Heterozygous allele (I/D) for an individual, however, has a moderate level of the angiotensin I-converting enzyme. Hence, this study aimed to determine the polymorphism association $A C E$ gene with PCOS patients of South Indian Cohort.

\section{MATERIALS AND METHODS}

\section{Study population}

The study includes PCOS patients $(n=430)$ and controls $(n=300)$ from a native South Indian population were recruited from Sandhya Hospital, Vellore, and have been approved by the Institutional Human Ethical Committee, VIT, Vellore, India. The PCOS was defined by the Rotterdam PCOS consensus criteria (Rotterdam, 2004). The control samples were recruited according to the 2003 Rotterdam Criteria by excluding the diagnosis of PCOS and having a normal cycle (b32 days). All individuals in the control group were healthy female and reproductively fit. All samples were collected after getting informed consent from donors. Data collection sheet included information such as personal profile including age, weight and height (Body mass index; BMI) and hormonal profile including Follicle-stimulating hormone (FSH), Luteinizing hormone (LH), Prolactin (PRL), Triiodothyronine (T3), Thyroxine (T4) and Thyroid-stimulating hormone (TSH). The blood test for screening hormone levels was taken on the second day of the menstrual period.

\section{Determination of angiotensin-converting- enzyme (ACE) genotype}

The genomic DNA from $2 \mathrm{ml}$ of venous blood was extracted according to Abilash et al. (2016) and stored at $-20^{\circ} \mathrm{C}$ deep freezer. The quality of DNA was checked by using Agarose gel electrophoresis. Amplification of $A C E$ gene was carried using forward primer 5'-CTG GAG ACC ACT CCC ATC CTT TCT-3' and reverse primer 5'-GAT GTG GCC ATC ACA TTC GTC AGA T-3' and performed in Eppendorf PCR Machine using a $20 \mu \mathrm{l}$ PCR mixture contained $10 \mathrm{pmol}$ from each primer, $5 \mu \mathrm{l}$ water and $10 \mu \mathrm{l}$ master mix (Ampliqon). DNA sample $(3 \mu \mathrm{l})$ was amplified for 35 cycles with an initial denaturation for 5 minutes at $95^{\circ} \mathrm{C}$ followed by denaturation at $95^{\circ} \mathrm{C}$ for 45 seconds, annealing at $59^{\circ} \mathrm{C}$ for 45 seconds, an extension for 1 minute at $72^{\circ} \mathrm{C}$ and final extension for 10 minutes at $72^{\circ} \mathrm{C}$ which resulted in a $490 \mathrm{bp}$ product. The PCR products were run on $2 \%$ agarose gel electrophoresis containing $5 \mu \mathrm{l}$ ethidium bromide $(50 \mu \mathrm{g} / \mu \mathrm{l})$ and were visualized using a UV Transilluminator. The results were photographed by gel documentation system and analyzed using the gel analysis software.

\section{RESULTS}

The clinical characteristics, namely age and BMI, were evaluated among PCOS and control groups. The differences between these two groups, however, were not statistically significant $(p>0.05)$ (Table 1). When tested the hormonal profiles (FSH, LH, PRL, T3, T4, TSH) of each group, the differences were statistically significant $(p<0.05)$ 
(Table1). Our PCR results showed that an intense band of 190 bp was detected with deletion (D) allele and $490 \mathrm{bp}$ with insertion (I) allele, whereas heterozygous (I/D) individual exhibited two bands (490 and $190 \mathrm{bp)} \mathrm{(Figure} \mathrm{1).}$

The frequency distribution of $A C E$ gene I/D genotype polymorphism frequency distribution in PCOS patients and controls were analyzed (Table 2). There was a statistically significant $(p<0.05)$ difference in the genotype distribution and allele frequencies between the PCOS patients and control groups. The genotyping distribution in PCOS for II, DD and ID among PCOS patients was $4.56 \%, 30.23 \%$, and $65.11 \%$, respectively, whereas the control group exhibited 30\%, 20\% and $50 \%$ for II, DD and ID, respectively. The deletion allele (D) frequency in PCOS was $62.79 \%$ and insertion allele (I) was $37.2 \%$. In the control group, the deletion allele (D) frequency and insertion allele (I) was 45 and 55\%, respectively (Table 3).

Figure 1. $A C E$ gene I/D polymorphism of PCOS using PCR-RFLP analysis.

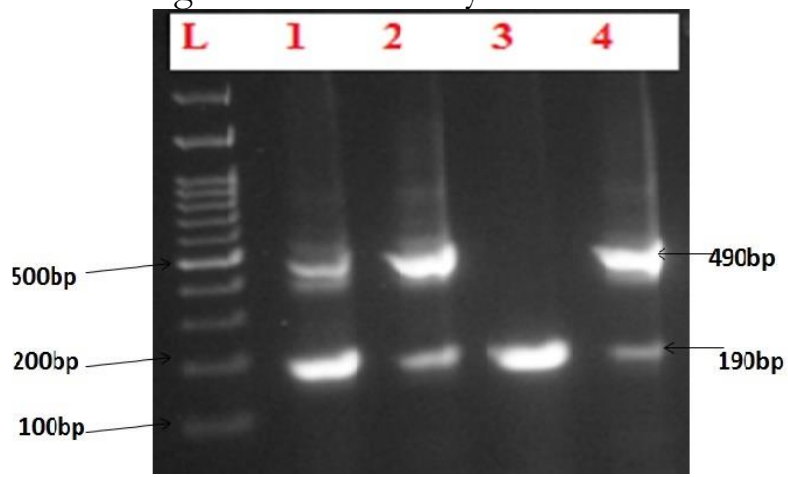

L: 100 bp DNA Ladder, Lane 1: ID (Heterozygous), Lane 2: ID (Heterozygous), Lane 3: DD (Homozygous), and Lane 4: ID (Heterozygous).

Table 1. Clinical characteristics of PCOS patients and controls.

\begin{tabular}{cccc}
\hline Individual features & Controls & Patients & P value \\
\hline Age (year) & $24.83 \pm 2.57$ & $24.19 \pm 4.12$ & $>0.05$ \\
$\mathrm{BMI}\left(\mathrm{kg} / \mathrm{m}^{2}\right)$ & $27.23 \pm 5.11$ & $28.42 \pm 6.73$ & $>0.05$ \\
$\mathrm{FSH}(\mathrm{mIU} / \mathrm{ml})$ & $16.99 \pm 2.74$ & $6.17 \pm 2.02$ & $<0.0001$ \\
$\mathrm{LH}(\mathrm{IU} / \mathrm{ml})$ & $9.72 \pm 3.74$ & $16.90 \pm 3.99$ & $<0.0001$ \\
$\mathrm{PRL}(\mathrm{ng} / \mathrm{ml})$ & $27.85 \pm 19.09$ & $18.41 \pm 5.96$ & $<0.05$ \\
$\mathrm{~T} 3(\mathrm{ng} / \mathrm{dl})$ & $157.71 \pm 26.15$ & $130.47 \pm 35.40$ & $<0.05$ \\
$\mathrm{~T} 4(\mathrm{ng} / \mathrm{dl})$ & $8.00 \pm 3.16$ & $9.39 \pm 2.59$ & $<0.05$ \\
$\mathrm{TSH}(\mathrm{mIU} / \mathrm{ml})$ & $2.41 \pm 0.83$ & $3.10 \pm 1.73$ & \\
\hline
\end{tabular}

Table 2. The frequency of the $A C E$ gene I/D polymorphism genotypes between PCOS patients and controls.

\begin{tabular}{cccccc}
\hline Genotype & Controls & Patients & P value & OR & $\mathbf{9 5 \%}$ CL \\
\hline II (HOMO) & 90 & 20 & & & \\
DD (HOMO) & 60 & 130 & $<0.0001$ & 9.75 & $5.497,17.29$ \\
ID & 150 & 280 & $<0.0001$ & 8.4 & $4.976,14.18$ \\
(HETERO) & 135 & 270 & $<0.0001$ & 9 & $5.314,15.24$ \\
D Allele & 165 & 160 & $<0.0001$ & 4.364 & $2.565,7.423$ \\
I Allele & 160
\end{tabular}

Table 3. The percentage of genotypes and allele frequencies between PCOS patients and controls.

\begin{tabular}{cccccc}
\hline \multirow{2}{*}{ Genotypes } & \multicolumn{2}{c}{ Distribution of genotypes } & \multicolumn{2}{c}{ Allele frequencies } \\
\cline { 2 - 6 } & II(Homo) & DD(Homo) & ID(Hetero) & D Allele (\%) & I Allele (\%) \\
\hline Patients & $4.65 \%$ & $30.23 \%$ & $65.11 \%$ & $63.00 \%$ & $37.00 \%$ \\
Controls & $30.00 \%$ & $20.00 \%$ & $50.00 \%$ & $45.00 \%$ & $55.00 \%$ \\
\hline
\end{tabular}


In this study, we could not find any specific association of $A C E$ gene polymorphism and clinical features between PCOS patients and control group. However, based on probability, this study supports the association of $\mathrm{D}$ allele in the $A C E$ gene I/D polymorphism and may be more common over PCOS patients of the South Indian cohort. Our study was in agreement with the study carried by Deepak et al. (2013), whereby the authors reported that the genotype distribution of DD, ID and II in PCOS patients was 39,37 , and $24 \%$, respectively, and it was 31 , 51 , and $18 \%$ for the genotype distribution of DD, ID and II, respectively, in the control group. The authors also concluded that the DD genotype of $A C E \mathrm{I} / \mathrm{D}$ gene polymorphism in an individual has predisposition and ID genotype has protective towards PCOS. Individuals with D allele of a single or double dose may develop early symptoms of PCOS and significantly associated with acanthosis (Deepika et al., 2013).

Another study led by Jia et al. (2013) who used a more precise estimation to analyze the association between I/D polymorphism of the $A C E$ gene and risk of PCOS. The author found that no significant association was observed in the overall population. However, in subgroup analyses stratified by ethnicity, a significant association was observed in Caucasians but not in Asians (Jia et al., 2013). Koika et al. (2012) found that there was a significant increase in the frequency of DI genotype in Greek origin when analyzing the $A C E$ gene I/D polymorphism in the PCOS. They also found an association of II genotype with insulin resistance (Koika et al., 2012). For Turkey women with PCOS, Bayram et al. (2011) found that their D allele frequency and homozygous DD were significantly higher than controls. The PCOS have 56\% DD, 24\% ID and $20 \%$ II genotypes compared to $28 \%$ DD, $47 \%$ ID, and 25\% II, respectively, in controls (Bayram et al., 2011).

\section{CONCLUSION}

Our study indicated that a strong association of D allele in the $A C E$ gene I/D polymorphism could be the reason for causing the development of PCOS in women of South Indian origin. To validate our data, further research by including other geographical areas of a country is needed since the variation in the ethnic background may also play a major role in gene pools.

\section{ACKNOWLEDGMENTS}

The authors are indebted to patients and extremely grateful to Dr. Sandhya Babu, Sandhya Hospital, Vellore, India, for providing us with the samples. The authors are grateful to Dr. Sudhakaran, VIT, for helping us to carry out the molecular study and the authors would like to thank the VIT management for providing all the facilities needed for this study.

\section{REFERENCES}

Abilash, V. G., Radha, S., Marimuthu, K. M., Thangaraj, K., Arun, S., Nishu, S., \& Anuradha, D. 2016. Clinical, cytogenetic and molecular analysis of androgen insensitivity syndromes from south Indian cohort and detection and in-silico characterization of androgen receptor gene mutations. Clinica Chimica Acta 453: 123-130.

Azziz, R., Carmina, E., Dewailly, D., Diamanti-Kandarakis, E., Escobar-Morreale, H. F., Futterweit, W., Janssen, O. E., Legro, R. S., Norman, R. J., Taylor, A. E., \& Witchel, S. F. 2009. The Androgen Excess and PCOS Society criteria for the polycystic ovary syndrome: the complete task force report. Fertility and Sterility 91(2): 456-488.

Bayram, B., Kılıççı, Ç., Önlü, H., Özkurt, M., Erkasap, N., Yıldırım, E., \& Şahin, F. 2011. Association of angiotensin converting enzyme (ACE) gene I/D polymorphism and polycystic ovary syndrome (PCOS). Gene 489(2): 86-88.

Brassard, M., AinMelk, Y., \& Baillargeon, J. P. 2008. Basic infertility including polycystic ovary syndrome. Medical Clinics of North America 92(5): 1163-1192.

Deepika, M. L. N., Reddy, K. R., Rani, V. U., Balakrishna, N., Latha, K. P., \& Jahan, P. 2013. Do ACE I/D gene polymorphism serve as a predictive marker for age at onset in PCOS?. Journal of Assisted Reproduction and Genetics 30(1): 125-130.

Elshamaa, M. F., Sabry, S. M., Bazaraa, H. M., Koura, H. M., Elghoroury, E. A., Kantoush, N. A., Thabet, E. H., \& AbdEl Haleem, D. A. 2011. Genetic polymorphism of ACE and the angiotensin II type1 receptor genes in children with chronic kidney disease. Journal of Inflammation 8(1): 20.

Glorioso, N., Atlas, S. A., Laragh, J. H., Jewelewicz, R., \& Sealey, J. E. 1986. Prorenin in high concentrations in human ovarian follicular fluid. Science 233(4771): 1422-1424.

Goodarzi, M. O. \& Azziz, R. 2006. Diagnosis, epidemiology, and genetics of the polycystic ovary syndrome. Best Practice \& Research Clinical Endocrinology \& Metabolism 20(2): 193-205.

Itskovitz, J., Sealey, J. E., Glorioso, N., \& Rosenwaks, Z. 1987. Plasma prorenin response to human chorionic gonadotropin in ovarian-hyperstimulated women: correlation with the number of ovarian follicles and steroid 
hormone concentrations. Proceedings of the National Academy of Sciences, 84(20): 7285-7289.

Jaatinen, T. A., Matinlauri, I., Anttila, L., Koskinen, P., Erkkola, R., \& Irjala, K. 1995. Serum total renin is elevated in women with polycystic ovarian syndrome. Fertility and Sterility 63(5): 1000-1004.

Jia, H., Wang, B., Yu, L., \& Jiang, Z. 2013. Association of angiotensin-converting enzyme gene insertion/deletion polymorphism with polycystic ovary syndrome: a metaanalysis. Journal of Renin-Angiotensin-Aldosterone System 14(3): 255-262.

Koika, V., Georgopoulos, N. A., Piouka, A., Roupas, N. D., Karela, A., Armeni, A. K., \& Panidis, D. 2012. Increased frequency of the DI genotype of the angiotensin-I converting enzyme and association of the II genotype with insulin resistance in polycystic ovary syndrome. European Journal of Endocrinology 166(4): 695-702.

Ożegowska K., Bartkowiak-Wieczorek J., Bogacz A., SeremakMrozikiewicz A., Duleba A. J., \& Pawelczyk, L. 2019. Relationship between adipocytokines and angiotensin converting enzyme gene insertion/deletion polymorphism in lean women with and without polycystic ovary syndrome. Gynecological Endocrinology 6:1-5.

Ożegowska, K., Bogacz, A., Bartkowiak-Wieczorek, J., Seremak-Mrozikiewicz, A., \& Pawelczyk, L. 2016. Association between the angiotensin converting enzyme gene insertion/deletion polymorphism and metabolic disturbances in women with polycystic ovary syndrome. Molecular Medicine Reports 4(6): 5401-5407.

Palumbo, A., Pourmotabbed, G., Carcangiu, M. L., AndradeGordon, P., Roa, L., DeCherney, A., \& Naftolin, F. 1993. Immunohistochemical localization of renin and angiotensin in the ovary: comparison between normal women and patients with histologically proven polycystic ovarian disease. Fertility and Sterility 60(2): 280-284.

Prapas, N., Karkanaki, A., Prapas, I., Kalogiannidis, I., Katsikis, I., \& Panidis, D. 2009. Genetics of polycystic ovary syndrome. Hippokratia 13(4): 216-223.

Rigat, B., Hubert, C., Alhenc-Gelas, F., Cambien, F., Corvol, P., \& Soubrier, F. 1990. An insertion/deletion polymorphism in the angiotensin I-converting enzyme gene accounting for half the variance of serum enzyme levels. Journal of Clinical Investigation 86(4): 1343-1346.

Rotterdam ESHRE/ASRM-Sponsored PCOS Consensus Workshop Group. 2004. Revised 2003 consensus on diagnostic criteria and long-term health risks related to polycystic ovary syndrome (PCOS). Human Reproduction, 19(1): 41-47.

Sayed-Tabatabaei, F. A., Oostra, B. A., Isaacs, A., Van Duijn, C. M., \& Witteman, J. C. M. 2006. ACE polymorphisms. Circulation Research 98(9): 1123-1133.

Yoshimura, Y. 1997. The ovarian renin-angiotensin system in reproductive physiology. Frontiers in Neuroendocrinology 18(3): 247-291.

Zawadzki, J. K. \& Dunaif, A 1992. Diagnostic criteria for polycystic ovary syndrome: towards a rational approach. In: Polycystic Ovary Syndrome. Ed. Dunaif, A. Givens J. R., Haseltine F. P. and Merriam G. R.; pp.377-384. Boston: Blackwell Scientific Publications. 